\title{
光学的計測法を用いた新しい 橋梁点検手法について*
}

The Development and Evaluation of Optical Measurement Techniques in Bridge Maintenance

\section{西村正三** \\ ShOZO NISHIMURA}

\section{1. 緒言}

高度経済成長期に建設された膨大な量のインフラの老朽 化が急速に進行し，危険レベルに達している．インフラの 老朽化を加速させる理由として, 効果的・効率的な検査法 がない，維持管理技術者不足，各自治体の予算不足等が挙 げられる ${ }^{1)}$ ，筆者は，従来の維持管理手法の改革が急務と 考え, 写真測量や 3D レーザスキャナに加え, ギガピクセ ル画像撮影や UAV (Unmanned Aerial Vehicle一無人飛行 体）等の最新の撮影手法を橋梁など鉄筋コンクリート構造 物（以下 $\mathrm{RC}$ 造）へ応用し, その有効性と有用性を確認し てきた ${ }^{2}$. 一方画像から $3 \mathrm{D}$ モデル生成の分野では, 写真 測量の発展型としての SfM (Structure from Motion) が 開発されている。これは, 従来レーザスキャナ等を用いて 生成していた $3 \mathrm{D}$ 点群を, デジタル画像から生成する技術 である、デジタルカメラは一般的な機器であり, リーズナ ブルで取り扱いが容易である. 本解説では, 主に外観劣化 情報取得を目的に，これまで実施してきた光学的計測法に ついて紹介する。

\section{2. デジタル画像・写真測量}

\subsection{3 次元形状取得技術}

構造物の維持管理を行うためには, 構造物の形状を詳細 に把握する必要がある。デジタルカメラ（以下 DSLR）や 3D レーザスキャナを用い，3 次元形状および表面の変状 を定量的に把握する. DSLRによる写真計測は，2 枚以上 の画像から対象物の 3 次元座標および表面のテキスチャ画 像を取得する。一方 3D レーザスキャナは構造物を点群と して計測するが, 高密度に計測しても亀裂幅までは読み取 れない

\section{2 デジタル画像を用いた調查}

橋梁などの大量な土木構造物の維持管理は定期点検（目 視）によって行っている. 点検や調查における点検員や足

*原稿受付 平成 26 年 8 月 19 日

**(株) 計測リサーチコンサルタント（広島市東区福田 1-665-1）
場を含むコストが膨大であり，点検のばらつきや見落とし も多く, 客観性や確実性がそしいとの課題があり, 最近は DSLR を用い，デジタル画像で記録することも多い，RC 造のひび割れを評価するには $0.2 \mathrm{~mm}$ 以上のひび割れ捕捉 が必要とされ ${ }^{3)}$, DSLR を用いた静止画撮影の事例では, 污 損のない明るい壁面の場合, 画像解像度の $1 / 10$ 程度まで の認識が可能である. 例えば, 撮影対象面を解像度 2 $\mathrm{mm} / \mathrm{pix}$ で撮影すれば $0.2 \mathrm{~mm}$ のひび割れまでが，また径 $30 \mathrm{~mm}$ のボルトの抜けを確認するための解像度は $3 \mathrm{~mm} /$ pix が必要であることを図 1 に示している. 図 2 は, 静止 撮影やトンネル調查の際の動的撮影など, 撮影条件の違い で各撮影機器を整理したものである. 特に長大橋点検の場 合には，仮設足場設置に伴う工期やコスト，また高所作業 やロープワークには安全性に課題がある。, 一方, 数十〜百 メートルの遠望からの撮影に活用できる自動撮影雲台は, 撮影範囲内を所定のラップ率で連続的に撮影し, 膨大な画 像は専用ソフトにより一枚に合成処理できる。 また上空か ら対象物に近接して高解像度の画像を取得するには, UAVにDSLRなどを搭載して撮影することで可能と なる，以下では某斜張橋の調査に $3 \mathrm{D}$ レーザで基本形状を 取得した後, 自動撮影雲台とUAV を活用した例を紹介 する。

\section{3. 某コンクリート斜張橋での応用例}

\section{1 計測・解析の概要}

某斜張橋は, 幅員 $5 \mathrm{~m}$, 主塔高 $75 \mathrm{~m}$ の PC 斜張橋であ る。調查は主塔 P5（道路面から $50 \mathrm{~m}$ ）を対象に実施し た. 距離 $100 \mathrm{~m}$ の位置から自動撮影雲台を用いたギガピ クセル画像撮影と距離約 $20 \mathrm{~m}$ の位置から UAV 搭載の DSLR で撮影した画像から「ひび割れ幅判読図化システ ム」でひび割れ幅の算出を行い, 別途実施された特殊高所 作業者によるロープワーク点検調査結果 ${ }^{4)}$ (以下〔ロープ 調査了）との比較検証を行ったものである ${ }^{5)}$. また画像か ら 3D モデル生成の環境が整ってきたことを反映し多視点 画像 3D 構築についても試行した. 撮影箇所を図 3 に, 〔ロープ調査〕状況を図 4 に示す。また，解析処理のフロ 


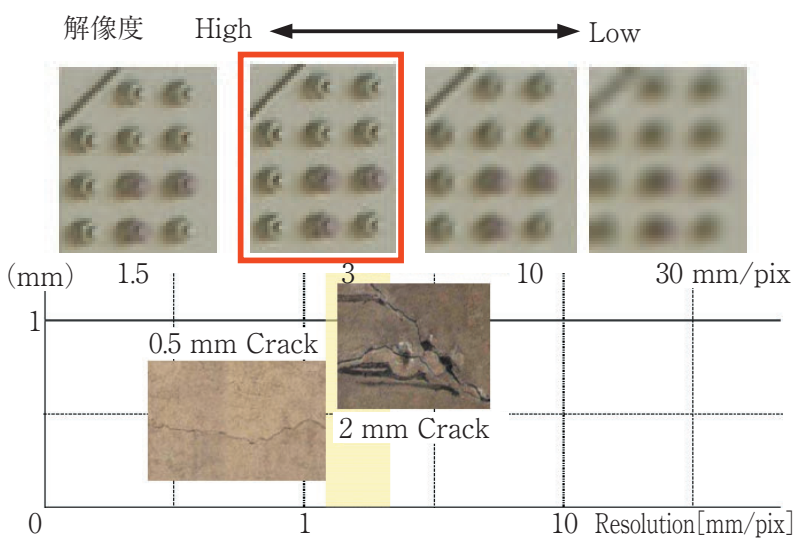

図 1 解像度と対象物の関係

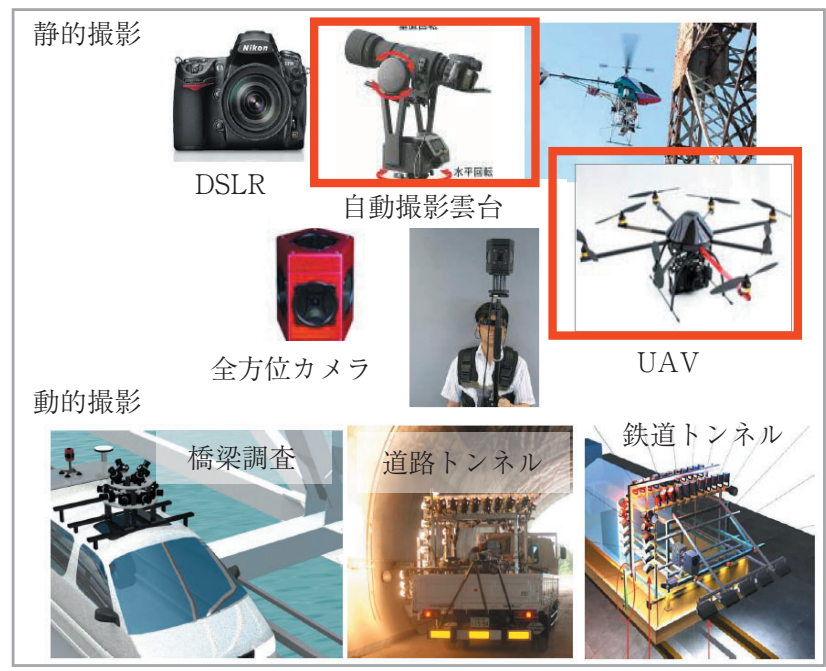

図2 デジタル画像撮影機器の分類

（静止～動的-移動·走行型）

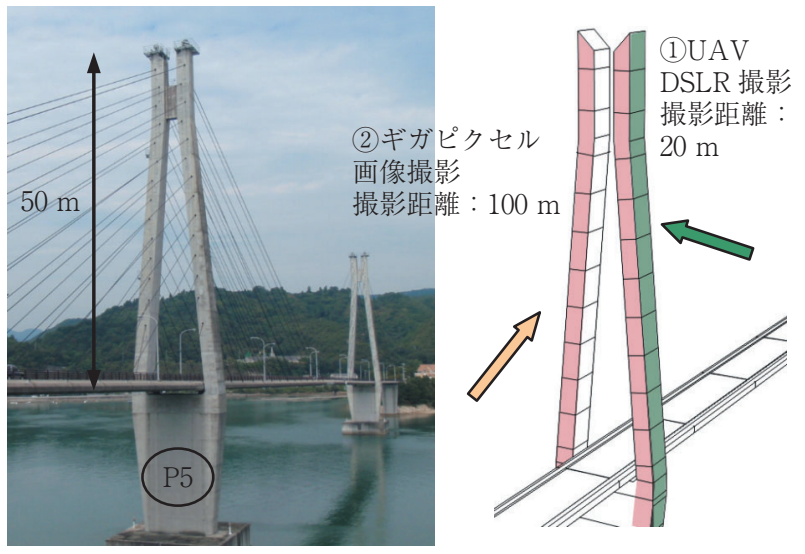

図 3 某斜張橋の計測位置図

一を図 5 に示す。

\section{2 ひび割れ幅判読図化システム}

コンクリートのひびわれ幅を評価するには $0.2 \mathrm{~mm}$ 以上 のひび割れ幅の計測が必要である。図 6 は，DSLRで（a) のクラックスケールを撮影すると, (b) の拡大画像に示

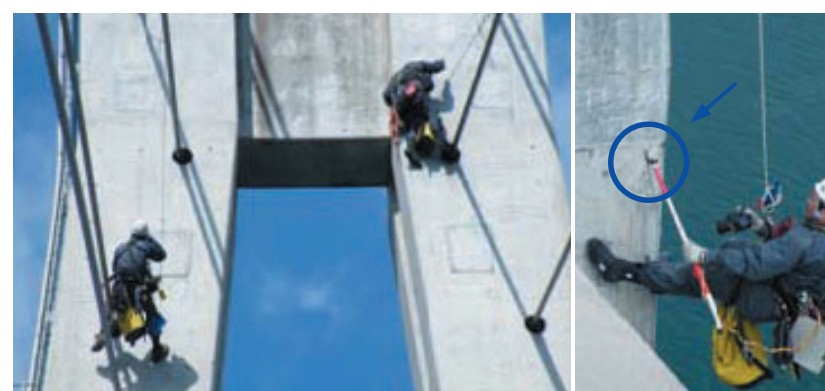

図 4 ロープワーク点検調查状況

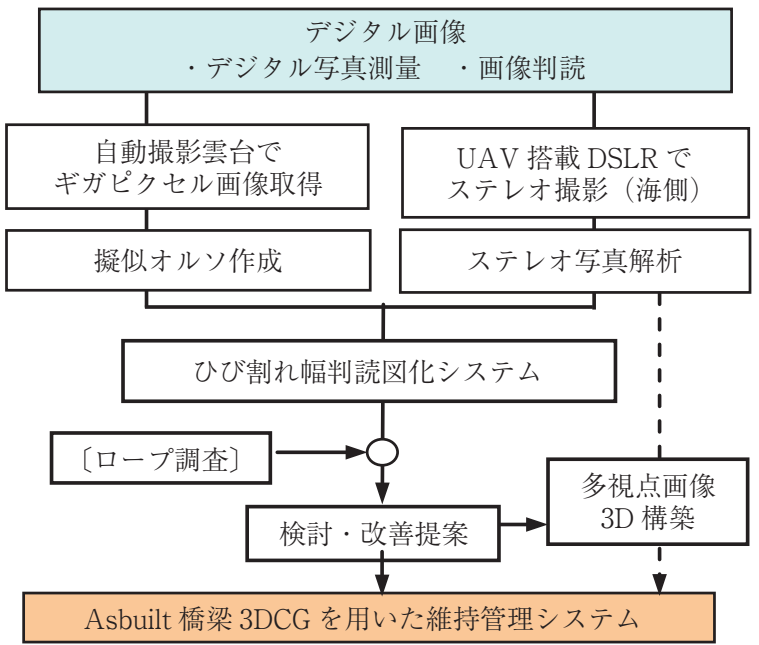

図 5 解析検討のフロー

(a)

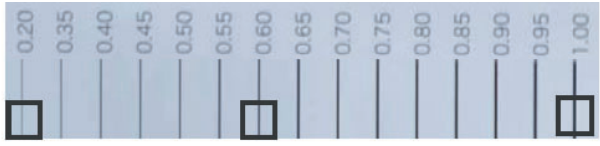

$0.2 \mathrm{~mm}$ $0.6 \mathrm{~mm}$

$1.0 \mathrm{~mm}$
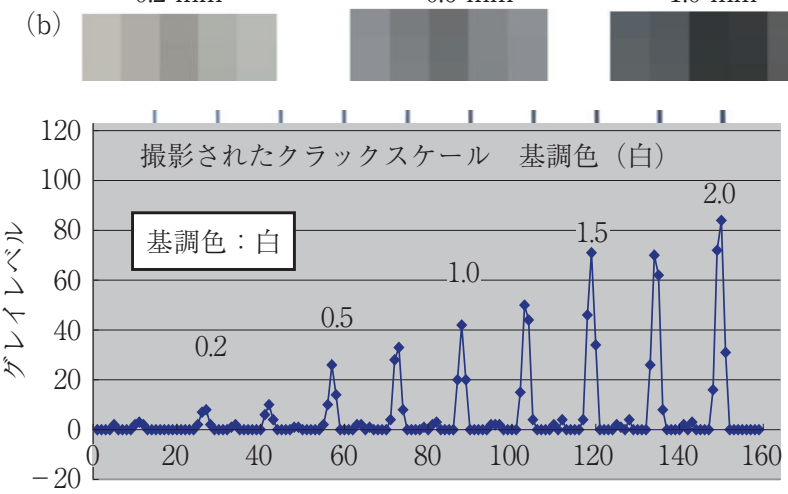

（c）クラックスケールを撮影した画像のグレイ階調

图 6 ひび割れのデジタルイメージ

すようにクラックは撮影取得され，(c) のサブピクセルレ ベルでグレイ階調表示できることを示している。これらの 事項から，ひびわれ幅はクラックインデックス（以下 $[\mathrm{CI}] ）$ 「特徵值 $\times$ 分布幅」という指標で表現できること を考案した（図 7)。〔CI]は分解能以下のクラックが CCD に取り込まれた際の, 各グレイ階調の総和であり, 


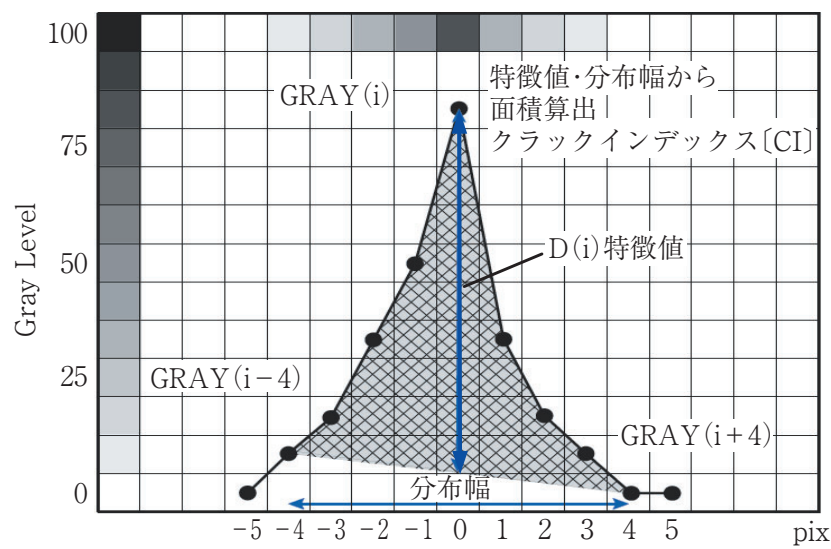

図 7 特徵值の計算手法模式イメージ

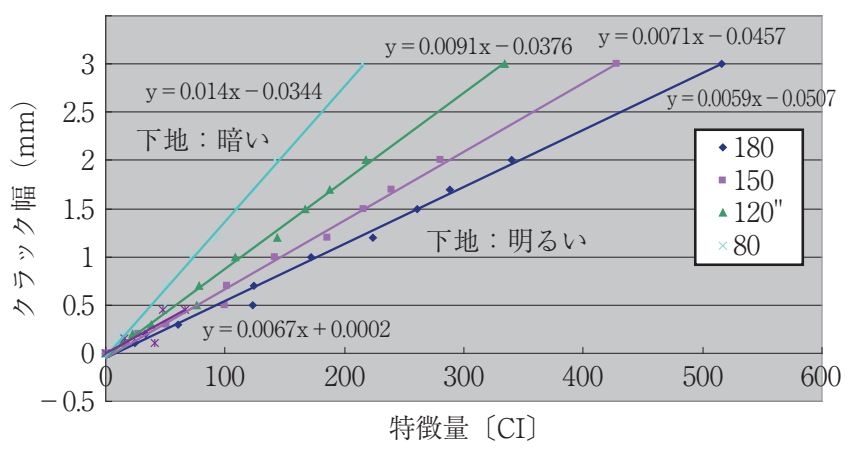

図８下地のグレイレベルとクラック幅算定の関係

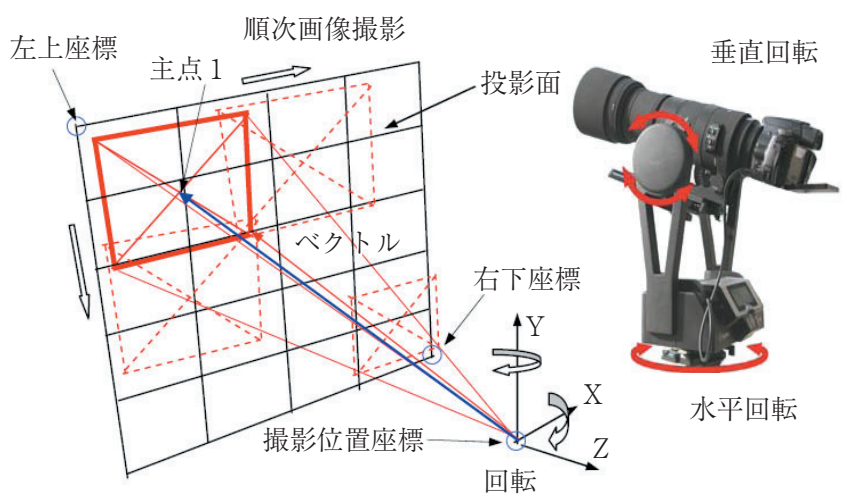

図 9 自動撮影雲台の機構と座標系

クラック幅が大きいと〔CI〕值も大きくなる。〔CI〕から クラック幅を定量的に算定・図化が可能なひび割れ幅判読 図化システムを構築し、ひび割れ幅の判読に普遍的に 〔CI〕を適用することが可能か否かを検証した，図８に示 すように，下地のグレイレベルが変化してもひび割れ幅と 〔CI〕值には高い相関がある。

\section{3 ギガピクセル画像を用いた擬似オルソ作成}

ギガピクセル画像撮影のうち駆動部の自動撮影雲台は, 2 軸のモータで設定した撮影範囲を自動分割し, 設置箇所 を中心に垂直，水平方向に回転しながら放射状に数百枚の 撮影を行う ${ }^{6)}$ (図 9). この数百枚の画像は, 数十億画素の
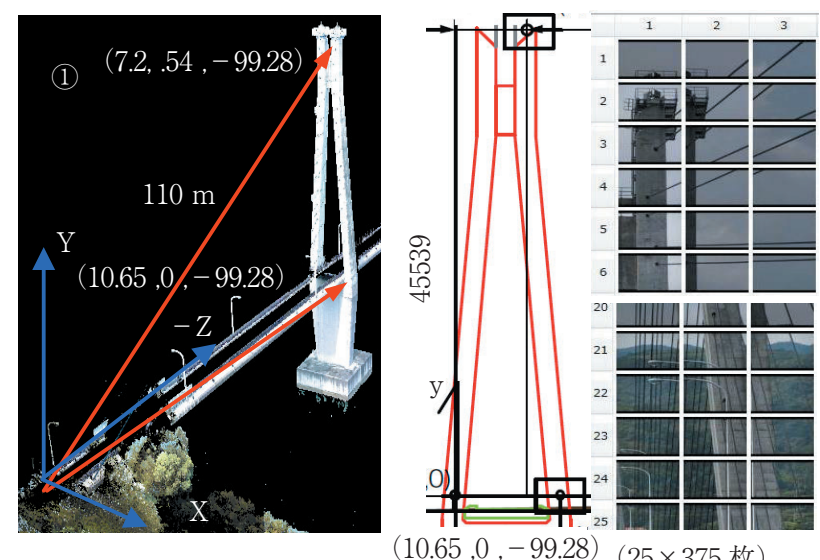

図 10 ギガピクセル画像撮影設定と詳細画像

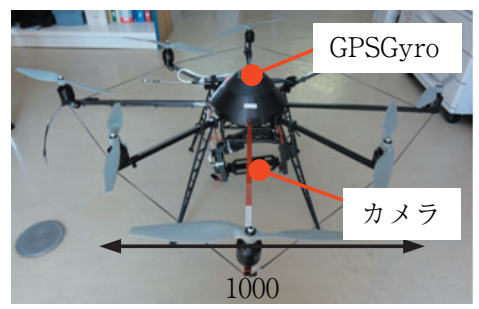

\begin{tabular}{l|l}
\hline 機体重量 & $1.3 \mathrm{kgf}$ \\
\hline 搭載重量 & $1.5 \mathrm{kgf}$ \\
\hline 耐風安定性 & $10 \mathrm{~m} / \mathrm{s}$ \\
\hline 飛行時間 & $\sim 15$ 分 \\
\hline 飛行距離 & $1 \sim 1.5 \mathrm{~km}$ \\
\hline
\end{tabular}

図 $11 \mathrm{UAV}$ の仕様

展開画像として合成される。今回対象までの撮影距離は, $110 \mathrm{~m}$ であり解像度 $1 \mathrm{~mm} / \mathrm{pixel}$ で設定すると，1枚あた りの撮影範囲は $3.1 \times 1.7 \mathrm{~m}$ の詳細撮影画像となる. 垂直, 水平方向に回転しながら縦 $25 \times$ 横 3 枚の計 75 枚の詳細画 像を得る（図 10）。この 75 枚から合成処理された展開画 像は数ギガバイトに及ぶが，画像を高〜低解像度のピラミ ッド構造にすることで通常の PCでもストレスなく拡大縮 小操作が可能である。 しかし一点から放射状に撮影・生成 された展開画像には歪が含まれるため, ひび割れ幅, 長さ などを正確には算出することができない，そのため詳細撮 影された画像ごとに幾何補正（射影変換）を行い，模擬的 にオルソ画像の作成を行う。処理は，まずカメラ位置と投 影面の空間座標系を設定し, 撮影開始, 終了点, 撮影位置 の座標と撮影の分割数を入力すると各詳細画像の回転角が 算出される。 カメラ位置と角度, カメラの画角から射影変 換を行い, 幾何補正条件と解像度を求め擬似的ではあるが オルソ画像を生成できる。

\subsection{UAV（無人航空体）を用いた外観調査}

UAV は機体にGPS とジャイロを搭載し, あらかじめ飛 行経路を設定しておくことで自動飛行により対象部位を詳 細に撮影することができる。搭載の GPS は 1 周波（誤差 $5 \mathrm{~m}$ 程度）であり，安全性確保のため構造物から $20 \mathrm{~m}$ を 確保して飛行した。図11に用いた機体の概要を示す. UAVにDSLR（画素数 $16 \mathrm{MP}$, 焦点距離 : $55 \mathrm{~mm}$ ) を搭 載しステレオ撮影した。 デジタル写真測量では，人工的な ターゲットを数点設置し高精度な測量を行った基準点を用 いる必要がある。しかし今回は地上 50 m の高所に位置す 

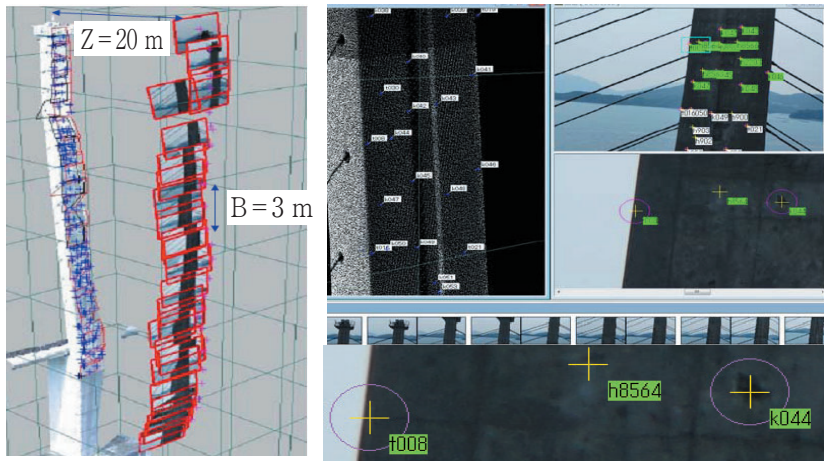

図 12 撮影形態求よび地物標定解析処理の状況
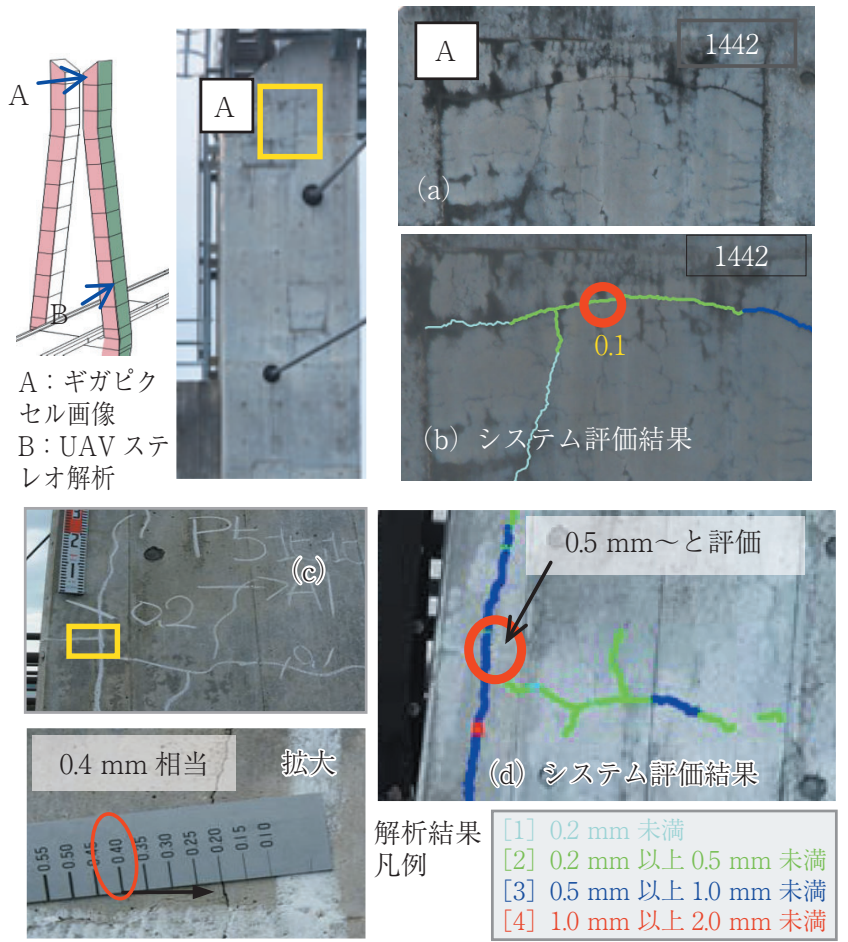

図 13 擬似オルソ画像（撮影距離：110 m)

るため $3 \mathrm{D}$ レーザの点群データを外部標定要素として用 い，モデル生成とひび割れ判読精度について検証した。対 象面に扔ける画像解像度は $2 \mathrm{~mm} / \mathrm{pix}$ 程度である。1コー スを上下に飛行させ，上下ステレオ撮影を行い，撮影枚数 は 25 枚である。図 12 に主塔に対する撮影形態掞よび解 析処理過程を示す。写真解析は, 全ステレオペアで, パス ポイント, タイポイントを手動で選定し,さらに3D レー ザ点群デー夕を用いて, バンドル調整計算により写真の外 部標定要素を同時に決定しお抄むね $30 \mathrm{~mm}$ 程度の解析結 果を得た。

\section{5 ひび割れ幅判読図化システムによる検証}

ギガピクセル画像撮影による擬似オルソ画像㧍よび UAV 画像のステレオ解析によるオルソ画像を用いてひび 割れ幅判読の検証を行った。擬似オルソ画像（解像度 1 $\mathrm{mm} / \mathrm{pix}$ ）の一部を図に示す. 箇所 A の疑似オルソ画像に よるひび割れ幅算定結果を図 13 (a)（b）に示す。〔ロー
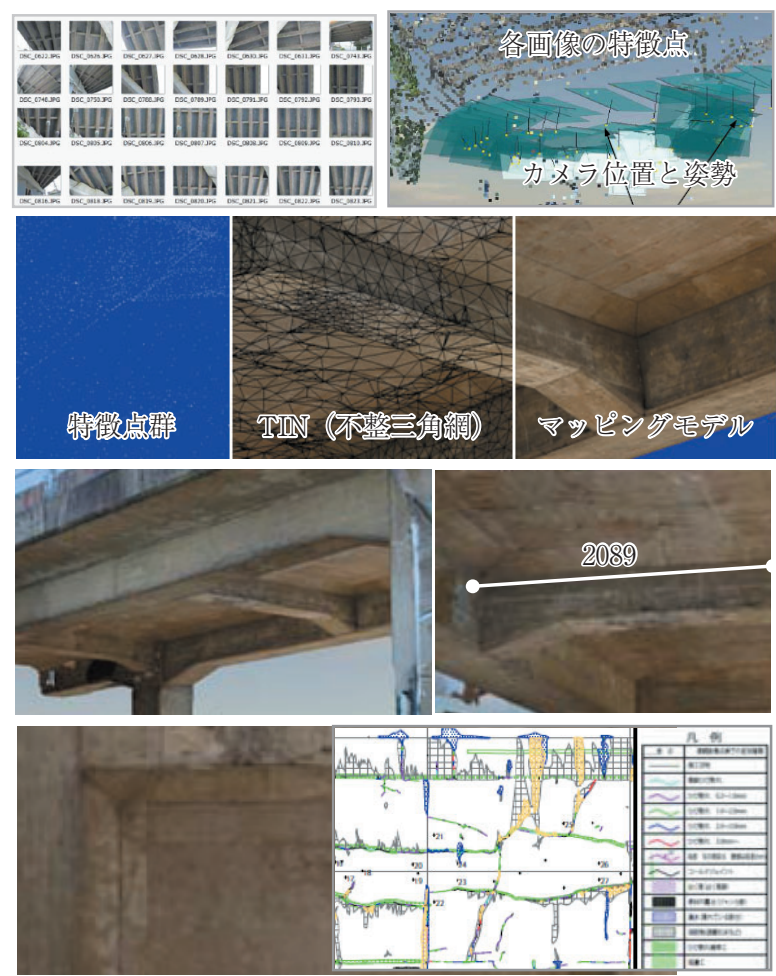

図 14 SfM一多視点画像 3D 構築の流れ

プ調査】で 0.1 と記述されている部位では（b） $0.2 \mathrm{~mm}$ 未 満の評価となった。箇所 B の〔ロープ調査〕およびUAV ステレオ解析で作成したオルソ画像を基に算出したひび割 れ幅を図 13 (c) (d) に示す。 UAV 画像の解像度は 2 $\mathrm{mm} / \mathrm{pix}$ であるが，〔ロープ調查〕で (c) $0.4 \mathrm{~mm}$ 相当の ものが, システム判定では（d） $0.5 \mathrm{~mm}$ 以上とほほ同等の 評価レベルが得られた。

\section{6 多視点画像 3D 構築の提案}

先述したように今回 UAV 画像からの写真測量では 3D レーザの点群デー夕を外部標定要素とし, パスポイントな どを手動で選定したがかなり時間を要した。一方，コンピ ユータービジョンの分野で開発されてきた SfM が, 写真 測量分野に拈いても応用が進み, 無料ソフトも公開され始 めてきた7 . SfM とは，あるシーンをカメラの視点を変え ながら撮影した複数枚の画像からそのシーンの 3 次元形状 とカメラの位置を同時に復元する手法である ${ }^{899}$. 以下で はSfM のアルゴリズムを元にした多視点画像計測手法を 用いた橋梁点検手法について紹介する ${ }^{10}$. 図 14 は DSLR を用い約 100 枚の画像を用いて床版を撮影し，3D モデル を構築した事例である.SfM により各写真の撮影位置が 計算され, 高解像度の画像がテクスチャマッピングされた 3D モデルが生成される。（a）床版撮影画像（100 枚程度） の各特徵点を自動認識し, 画像ごとのカメラ撮影位置を自 動解析. (b) 写真画像がマッピングされた $3 \mathrm{D}$ モデル生 成. (c) ビューアで任意方向からの閲覧と距離測定が可 能.（d）拡大表示すると, 元の撮影解像度のまま表面性 状を確認でき,ひび割れ幅判読図化システムで損傷図まで 

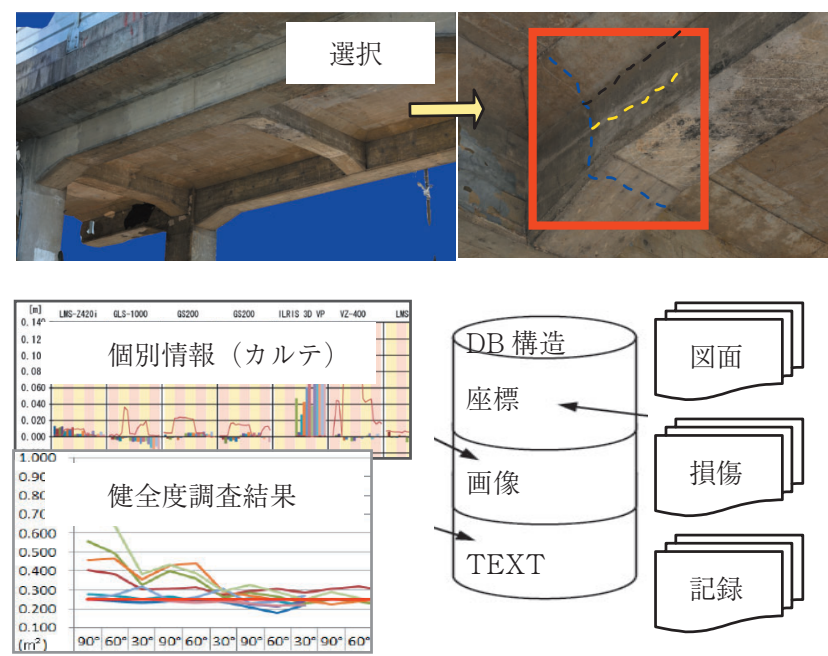

図 15 CIM3 次元モデルを活用した維持管理システム

の作成が可能となる.

解析に必要となる現地作業は, デジタルカメラによる多 方向から対象構造物を $60 \%$ 以上ラップさせて撮影を行う のみで $3 \mathrm{D}$ モデルが構築される. 本技術を橋梁の調査点検 に適用することで，現地作業の大幅な効率化が図れる，例 えば撮影のみを地域の NPO や地域住民に委嘱すれば, 地 方のインフラ長寿命化に大きく貢献することが可能とな る.そして撮影画像を集約し $3 \mathrm{D}$ 処理センター（仮称）で 処理・解析・DB 化することでより効率的な維持管理への 可能性がある.

\section{Asbuilt な 3 次元維持管理システム構築に向けて}

橋梁点検を的確に行うには, 効率的に必要かつ正確な情 報を捉えること，新旧情報の比較から将来を予測すること が重要となる, 従来の点検により得られた情報は, 変状箇 所のみの画像である場合が多い. 今回試行した遠隔から全 体像を俯瞰し, かつ高精度なデジタル画像取得が可能なギ ガピクセル画像やUAV 画像さらには多視点画像 3D 構築 などの手法を利用すれば, 全部材, 全部位の健全部も含め た情報が得られるため, 経年変化を把握するためのデータ として活用できる. またこれら光学的計測手法は, 足場架 設の制限を受けずに点検調査に活用でき支保工などの仮設 経費の削減が期待できる. 提案する光学的手法が確立する と, 肉眼では見ることができない, あるいは人間の眼を超 えた情報を取得・分析することができる。したがって

·高信頼性・高精度化による目視点検のばらつきの解消
・ インフラ点検の低コスト化による点検頻度増加

・定量的な損傷データの取得

・ 地震や台風等の自然災害直後の緊急調査

も可能となる.

取得した膨大な画像を迅速に検索・閲覧ができるために は 3 次元維持管理という概念も重要である。これまで整 備・蓄積されてきた膨大な道路・橋梁台帳などの維持管理 に関わる情報資産をCIM (Construction Information Modeling）と連携させて一括管理する. 提案した多視点 画像 3D で構築したモデルから市販の CIM ソフトに取り 込み, 橋梁の構成要素である桁, 床版, 橋脚などの属性ご とに情報化し，また点検記録の PDF データとリンクさせ ることができる. CIM の 3 次元モデル上に各種情報を格 納またはリンクさせることで, 部材や部位ごとに必要な情 報を迅速に収集が可能である. 3 次元モデルを用いた維持 管理システムのイメージを図 15 に示す. 損傷の 3 次元可 視化は, 損傷の連続性が確認しやすく変状原因の推定判断 を補助する上でも有効である.

\section{参 考 文 献}

1）国交省「道路橋の予防保全に向けた有識者会議」(http://www. mlit.go.jp/road/ir/ir-council/maintenance/index.html).

2) 西村正三他：軍艦島の調査・検証からみた今後のインフラ構造 物調査への提案, 日本実験力学会誌, 12, 3 (2012) 147-158.

3）JACIC：コンクリート診断技術’02 基礎編，（2002） 89.

4) 平成 20 年度 農業用施設維持事業 大芝大橋構造点検業務報告 書.

5）西村正三他：橋梁維持管理調査における遠隔計測手法の有効性 検証, (社) 日本測量協会 応用測量論文集.

6) 例えば http://gigapan.com/

7）例えば http://www.acute3d.com/

8）鳥居秋彦, 奥富正敏：安定・高精度なオンライン SfM, 画像の 認識・理解シンポジウム (MIRU2011), 2011 年 7 月.

9）満上育久: Bundler: Structure from Motion for Unordered Image Collections, 映像メディア学会誌，53，479-482.

10）小沼恵太郎他：多視点画像 $3 \mathrm{D}$ 構築技術の橋梁調査への適用性 について, 土木学会第 69 回年次学術講演会概要集 (CDROM), 2016.

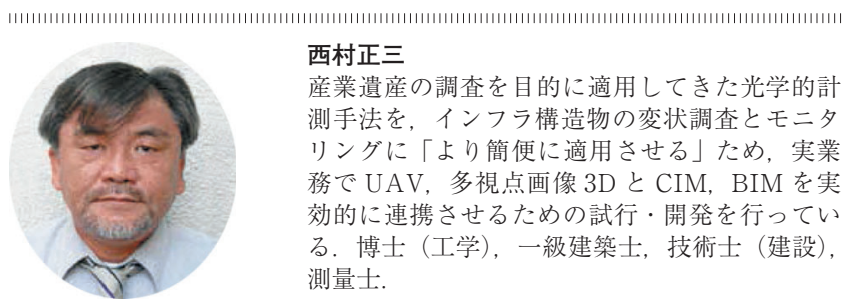

| 